\title{
Tsunami hazard mapping and loss estimation using geographic information system in Drini Beach, Gunungkidul Coastal Area, Yogyakarta, Indonesia
}

\author{
Muh Aris Marfai ${ }^{1}$, Sunarto ${ }^{1}$, Nurul Khakim ${ }^{2}$, Hendy Fatchurohman ${ }^{3}$, Ahmad Cahyadi $^{1}$, Yunus Aris Wibowo $^{3}$, \\ and Fredi Satya Candra Rosaji ${ }^{4}$ \\ ${ }^{1}$ Department of Environmental Geography, Faculty of Geography, Universitas Gadjah Mada, Indonesia \\ ${ }^{2}$ Department of Geographic Information Science, Faculty of Geography, Universitas Gadjah Mada, Indonesia \\ ${ }^{3}$ Master Program in Planning and Management of Coastal Area and Watershed, Universitas Gadjah Mada, Indonesia \\ ${ }^{4} \mathrm{CV}$. Mitra Geotama Mapping Consultant, Yogyakarta, Indonesia
}

\begin{abstract}
The southern coastal area of Java Island is one of the nine seismic gaps that prone to tsunamis. The entire coastline in one of the regencies, Gunungkidul, is exposed to the subduction zone in the Indian Ocean. Also, the growing tourism industries in the regency increase its vulnerability, which places most of its areas at high risk of tsunamis. This conditions are expected to increase the tsunami risk and loss potential alongside the coastal area. This research aims to model tsunami inundation and estimate the loss that caused by tsunami. Detailed DEM generated from UAV photogrammetry. Based on the model, several inundation scenario. Based on the model, the 4-m inundation did not affect a wide area. The modelling proves that the extent of tsunami-inundated areas is directly proportional to the wave height of tsunamis. The inundated area extend as the inundation scenario increase. Hilly karst topography prevent the water to inundate wider areas. The loss calculation shows that the material loss at the trading centre was relatively much higher than the other land uses because its included not only the value of the building but also the commodities and the strategic importance of their market
\end{abstract}

\section{Introduction}

Tsunami is one of the disaster events that have a massive impact on life $[1,2]$. It poses serious threats to many coastal communities in many parts of the world because it can inundate low-lying areas in a short time. It is a series of long waves in an extended period generated by the sudden deformation of seafloor or caused by other sudden disturbances [3]. The generation mechanism can be attributed to (1) submarine earthquakes triggered by tectonic plate subduction, (2) landslides on the ocean floor and (3) terrestrial events in areas adjacent to the sea, such as volcanic eruptions, landslides and rock falls [3-6].

Tsunamis in Indonesia are mostly caused by earthquakes [7,8]. Indonesia lies between two oceans (the Pacific and Indian Oceans) and two continents (Australia and Asia). Situated in the meeting point of three highly active tectonic plates (Eurasian, IndiaAustralia and Pacific plates), this archipelagic country is prone to earthquakes and tsunamis [9-12]. Java Island (the Sunda Arc) is produced by the subduction of the India and Australian Plates, creating an inherently susceptible environment to tsunami occurrences $[10,11,14,15]$.

As a natural hazard or threat, tsunamis can be fatal to human life. Natural hazards are defined as events that threaten and can create damages to the environment [10].
Aside from environmental disturbances, these threats potentially cause harm to and loss of human lives, properties and other components. Hazards can also create risks and possibly turn into disasters if vulnerable elements are affected by $[3,15]$. Tsunamis can cause massive damages to buildings and infrastructures and even casualties [18] Therefore, tsunami hazard studies, as the first step in disaster preparedness and mitigation, are necessary.

Studies of tsunamis or coastal disasters can rely on the combination of hydrological modelling and Geographic Information System (GIS) [5,20]. GIS can be used to assess the vulnerability models of various natural hazards, mainly because there are many analytical methods applicable to it. Integrating multiple data sources, it provides significant assistance to creating thematic maps related to tsunamis. One of the primary databases for assessing tsunami hazards is Digital Elevation Model (DEM). DEM is an essential and significant topographic product that can be applied in various fields.

DEM acquisition with conventional terrestrial survey and remote sensing is considerably costly [21]. In the last years, topographic data acquisition with Unmanned Aerial Vehicle (UAV) has been widely used to overcome this problem. UAV has several advantages, namely low cost, ability to provide up-to-date data, a very detailed spatial resolution and specific suitability for topographic

\footnotetext{
* Corresponding author: arismarfai@ugm.ac.id
} 
mapping in relatively narrow areas [22]. This study aimed to 1) perform a detailed topographic mapping with UAV to provide the basis for tsunami hazard classification in Drini Beach, Gunungkidul, Yogyakarta, Indonesia and 2) identify the potential damages and losses based on tsunami hazard modelling.

\section{Study area}

The coastal area in Gunungkidul Regency has a distinctive gently sloping beach with white sand-the results of karst dissolution-and various coastal forms [12]. Therefore, along with the coastal areas in Java Island, it has developed rapidly into a tourist attraction, and the tourism sector has contributed substantially to the local income of Gunungkidul after tax revenue. The high tourism activity, however, increases the vulnerability of coastal areas in Gunungkidul to tsunamis. Moreover, these areas face directly to the source, i.e., the subduction zone on the south of Java Island that creates the seismic gaps where tsunamis with large magnitudes potentially occur. The same tourism growth and vulnerability to tsunamis are found in Drini coastal area, located at $8^{\circ} 0818.3^{\prime \prime} \mathrm{S}$ and $110^{\circ} 3444.7^{\prime \prime} \mathrm{E}$ (Figure 1).

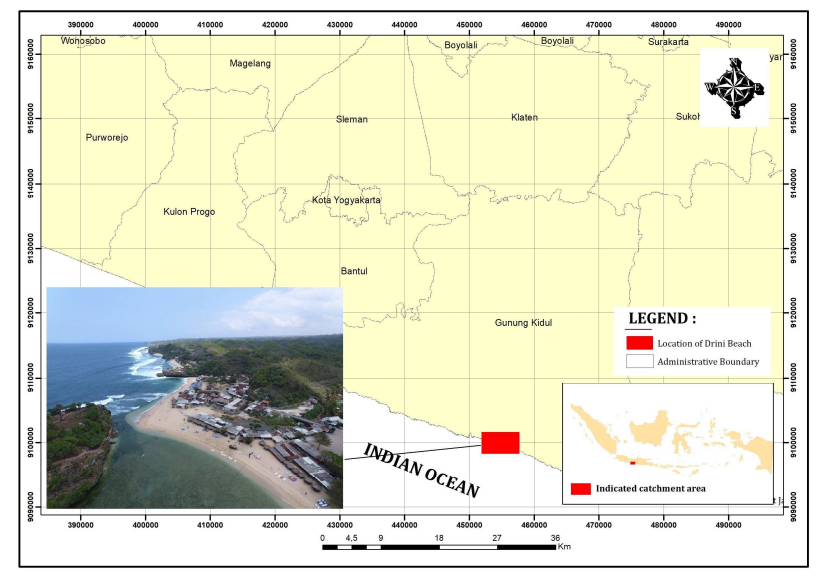

Fig. 1. Location of Drini Coastal Area.

\section{Methods}

\subsection{Acquisition of aerial photos}

This study started with planning the flight route for the UAV and installing the pre-marks or marks for ground control point measurement. Two flight routes were predetermined to record the coastal areas in Gunungkidul at an altitude of approximately $300 \mathrm{~m}$ above the ground. There were ten pre-marks (Figure 2) distributed in the field, which represented the topographic configuration of the study area. The coordinates were measured with a geodetic Global Positioning System (GPS) using the Real Time Kinematic (RTK) method.

This study used a fixed-wing aircraft with a Bixler airframe. The UAV was controlled semi-automatically, i.e., using an autopilot component to direct it toward the planned flight route while in the air. The pilot controlled it only at the time of take-off and landing and the copilot observed its movement and position from the Ground Control Station (GCS). The UAV was equipped with a pocket camera Canon Powershot A2500 with $16 \mathrm{Mpix}$ resolution as a sensor. The camera was set to capture images automatically every two seconds with a shutter speed of $1 / 2000$ to avoid blurry photos.



Fig. 2. The pre-marks for UAV photography, as appeared on the ground (left) and in the aerial photo (right).

The aerial photograph data aqcuisition was conducted in March, 2017. By providing the most recent DEM data based on aerial photograph, the elevation and land use data are expected to give more accurate analysis on the inundation model and loss estimation.

\subsection{DEM generation}

As in [10] and [20] used GIS approach with Digital Elevation Model (DEM) as the data input to determine the depth of tidal floods and the affected areas in Semarang, Central Java. [20] also used DEM for tsunami modelling in Muscat, Oman. However, the availability of detailed DEM is often limited, which becomes the main obstacle in modelling. Therefore, this study applied UAV technology to obtain a detailed DEM because the modelling of inundations caused by river flood, tidal flood, lahar and tsunami is highly sensitive to the difference in elevation. DEM can describe the topographic condition of a region. The more detailed it is, the better and more accurate the results are.

The aerial photos obtained by the UAV store altitude information, which is reflected in each pixel value. Therefore, the topographic data (DEM) of the study area can be produced from these photos. The results of UAVassisted recording are photos that are partially overlapping with each other forming an image sequence with a Ground Sample Distance (GSD) of $\pm 9 \mathrm{~cm} /$ pixel. UAV photography certainly gives detail to objects in relatively high areas. Accordingly, it is expected to facilitate the interpretation of the spatial data required in modelling. The data acquired from UAV photography were processed in Agisoft Photoscan software. The DEM of the study area was obtained by uniting similar pixel value to form point clouds. Afterward, the georeferenced three-dimensional (3D) data were produced from the dense clouds. The topographic data (DEM) was generated from this sequential process Place the figure as close as possible after the point where it is first referenced in the text. If there is a large number of figures and tables it might be necessary to place some 
before their text citation. If a figure or table is too large to fit into one column, it can be centred across both columns at the top or the bottom of the page.

\subsection{Loss estimation}

To estimate the losses caused by tsunamis, this research used the tsunami vulnerability map of Drini coastal area that was composed of different inundation scenarios (depths of $4,6,8,10$ and $12 \mathrm{~m}$ ). This map was developed from DEM and modelling in GIS. It was overlaid with the existing land use map to determine the type and the extent of tsunami-affected land use in several scenarios. The land use map was the result of interpretation of aerial photographs produced by UAV, which had excellent resolution and were suitable as a base map for 1:5,000 land use map. Land use represents the potential economic loss per hectare if a tsunami strikes and damages the coastal area in Drini. This value represents the estimated market price of buildings and other assets per hectare in each type of land use $[10,20]$. The results of the overlay process of tsunami vulnerability map and land use map illustrated the maximum potential loss in the study area.

This research divided land use into six types, namely agricultural land, trading centre, fish pond, uniform settlement, non-uniform settlement and open land $[10,20]$. The cabins on agricultural land were assumed to have the same value as a non-uniform settlement. Uniform settlement is owned by people with upper middle to upper income, while non-uniform settlement is owned by people with lower middle to lower income. The estimated economic value per hectare for uniform settlement was $€ 1,200,000$, non-uniform settlement $€ 1,000,000$, farm $€ 80,000$, fish pond $€ 95,000$, business centre $€ 2,500,000$ and open land $€ 1,700[10,20]$. These figures were based on actual data at the time of research and scientifically tested findings of similar studies; thereby, they were reliable to describe the condition of the study area. The rough estimation of losses in this study may not be fully accurate, but it is applicable for risk assessment and the development of tsunami disaster mitigation.

\section{Results and discussion}

The aerial photograph mission was conducted from Sepanjang Beach to Krakal Beach in March, 2017, which produced 314 pgotos. The mission path for the flight depicted in Figure 3. The UAV used a large aircraft to withstand the strong winds in the coastal area. The flight $\log$ showed that the aircraft movement was relatively straight and neat. The camera used the triggerby-distance method, and the results showed that the distance between the photos was relatively uniform and regular. This condition corresponds to the maintained end/forward lap during the mission, which improves the quality of the results of orthophoto mosaic and Digital Surface Model (DSM) processing.

The detail and accuracy of the topographic data (DEM) acquired from UAV are suitable for tsunami inundation modelling [20]. In other words, the prediction of tsunami-inundated areas in different scenarios is reliable. The results of the modelling showed that in the scenario of 4-meters inundation, tsunami affected 7,705 ha of Drini Coastal Area. The most severely affected atrisk element in this scenario was the agricultural land (Fig. 4a), but in term of economic loss, the most significant asset loss was found at the trading centre inside the tourist attractions, i.e., Drini and Watu Kodok Beach, with an estimated loss of $€ 3,255,317$ (Table 2).

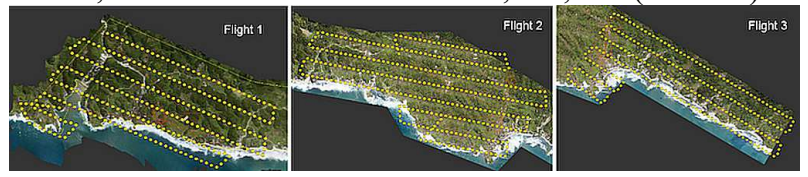

Fig. 3. The position of aerial photo and aircraft movement.

Due to the topography and coastal typology of the study area, the 4-m inundation did not affect a wide area. The modelling proves that the extent of tsunamiinundated areas is directly proportional to the wave height of tsunamis. However, the potential and capacity of at-risk elements to deal with tsunami have to be considered when estimating the effects of tsunamis. In the 6-meter scenario, a larger area was inundated (Figures 4.a and 4.b.). On the contrary, there was no significant increase in the extent of the affected areas in the 8, 10 and 12-m scenarios (Figures 4.c, 4.d and 4.e.) because of the topography and typology of Drini Coastal Area, which is bordered by karst hills on the north (landward).

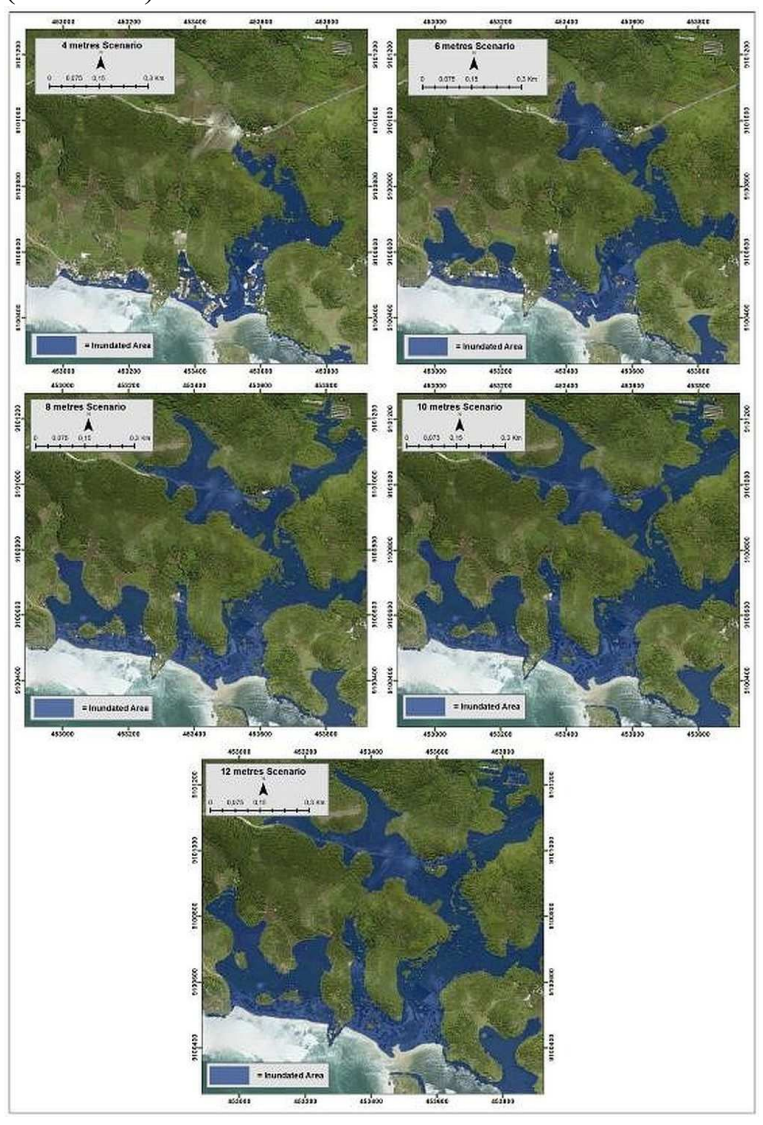

Fig. 4. Tsunami inundation modelling with different depth scenarios $(4,6,8,10$ and $12 \mathrm{~m})$ in Drini Coastal Area. 
Drini coastal area is a sandy cove dominated by the typology of marine deposition coast and wave erosion coast [12]. It is a gently sloping area directly adjacent to the sea (on the south) and hills (on the north, landward), which function as a natural barrier to tsunami waves. It is different from the relatively flat topography where even a shallow inundation can disturb a vast area. Moreover, flat areas tend to grow into tourist attractions and trading centres. If tsunamis strike them, the loss will be enormous even though they are located far from dense settlements.

In Drini, tsunami warning boards, evacuation routes and gathering points are available (Figure 5). However, the design of the shops and kiosks does not support the appropriate evacuation routes. For instance, there are tables and display cases in front of them, creating narrow doors and alleys that obstruct and delay evacuation process during an emergency. This condition is a contributing factor in risk assessment, particularly in the case of tsunamis that occur suddenly and leave a very short time for evacuation. Also, the different comprehension of tsunami hazards and the terrains between traders, local people and tourist also determines their ability to save themselves if a disaster strikes. The tsunami warning signs at tourist attractions are considered to be more efficient when added with the improvement of tourists' knowledge of tsunamis by officers in the field. This strategy is an attempt to increase the capacity of tourists to react appropriately to tsunami hazards and, in general, to reduce the potential losses.

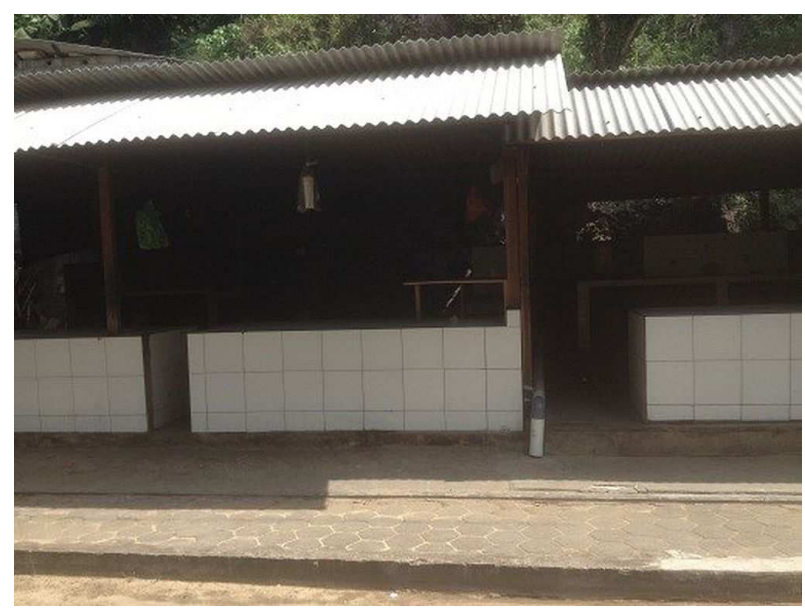

Fig. 5. Evacuation Route Signs (up); design of the shops that potentially delay the evacuation process (down).

\subsection{Estimated loss}

The tsunami simulations with different inundation scenarios, namely $4,6,8,10$ and $12 \mathrm{~m}$, showed a mixed result (Figure 4), including the different potential loss that was estimated with information from vulnerability map and land use map (Table 1).
Table 1. The extent of tsunami-affected area.

\begin{tabular}{|c|c|c|c|c|c|}
\hline \multirow{2}{*}{$\begin{array}{l}\text { Land use } \\
\text { types }\end{array}$} & \multicolumn{5}{|c|}{$\begin{array}{c}\text { Estimated damage in different inundation } \\
\text { scenarios (in hectares) }\end{array}$} \\
\hline & $4 \mathrm{~m}$ & $6 \mathrm{~m}$ & $8 \mathrm{~m}$ & $10 \mathrm{~m}$ & $12 \mathrm{~m}$ \\
\hline $\begin{array}{l}\text { Agricultural } \\
\text { land }\end{array}$ & 4.28 & 10.66 & 16.88 & 20.22 & 23.51 \\
\hline $\begin{array}{l}\text { Trading } \\
\text { centre }\end{array}$ & 1.15 & 2.24 & 2.97 & 3.24 & 3,68 \\
\hline Fish pond & 0.21 & 0.22 & 0.22 & 0.22 & 0.22 \\
\hline Open land & 1.59 & 2.05 & 2.40 & 2.62 & 2.86 \\
\hline Cabin & 0.01 & 0.03 & 0.05 & 0.06 & 0.06 \\
\hline Road & 0.19 & 0.46 & 0.73 & 0.84 & 0.94 \\
\hline Water body & 0.27 & 0.28 & 0.28 & 0.28 & 0.29 \\
\hline Total & 7.71 & 15.94 & 23.54 & 27.49 & 31.56 \\
\hline
\end{tabular}

In all scenarios, the most widely affected land use was agricultural land, while the land use with the enormous potential loss was the trading centre (Table 1) because it was located in a gently sloping area and adjacent to the sea. The vulnerability map was developed based on the data acquired from UAV and modelling in GIS, while the existing land use map was produced from the interpretation of the aerial photographs that had been tested for accuracy (Figure 6). In the 4-m scenario, the estimated loss was the lowest compared to other



scenarios with deeper inundation (Table 2).

Fig. 6. Landuse map of Drini Coastal Area

Furthermore, the material loss at the trading centre was relatively much higher than the other land uses because the loss estimation included not only the value of the building but also the value of the commodities and the strategic importance of their market. Although the agricultural land was the most extensively affected land use in all inundation scenarios, its potential loss was not as massive as the trading centre because the commodity value and the strategic value of agricultural market were 
low. The study area is a solutional landform where limestone material is dominant; therefore, the farming sector is less developed compared to the same industry in fertile alluvial plains and easily accessible regions. The potential loss increased consistently with the increase of inundation area in each scenario. The loss in the 4-m scenario rose significantly (nearly $100 \%$ ) when the inundation became deeper, i.e., $6 \mathrm{~m}$. However, there was insignificant difference $(30 \%)$ between the economic losses in the $6,8,10$, and $12-\mathrm{m}$ scenarios (Table 2). The results of these simulations are attributed to the trading centre and agricultural land that are estimated to receive the most impact of tsunamis, mainly because the coastal area in Drini is far from dense settlements.

Table 2. The estimated loss in tsunami-affected areas in different inundation scenarios.

\begin{tabular}{|l|c|c|c|c|c|}
\hline \multirow{2}{*}{ Land use types } & \multicolumn{5}{|c|}{ Estimated loss in different inundation scenarios (Euro) } \\
\cline { 2 - 6 } & $\mathbf{4 ~ \mathbf { ~ }}$ & $\mathbf{6 ~ \mathbf { ~ }}$ & $\mathbf{8 ~ \mathbf { ~ }}$ & $\mathbf{1 0 ~ \mathbf { ~ }}$ & $\mathbf{1 2 ~ \mathbf { ~ }}$ \\
\hline $\begin{array}{l}\text { Agricultural } \\
\text { land }\end{array}$ & 342.5 & 853.18 & 1350.07 & 1617.4 & 1880.53 \\
\hline Trading centre & 2884.22 & 5589.14 & 7437.28 & 8108.1 & 9206.36 \\
\hline Fish pond & 20.414 & 20.792 & 21.249 & 21.25 & 21.25 \\
\hline Bareland & 2.696 & 3.490 & 4.084 & 4.4 & 4.85 \\
\hline Shack & 5.479 & 27.981 & 46.883 & 61.3 & 64.9 \\
\hline Total & 3255.317 & 6494.589 & 8859.568 & 9812.578 & 11177.904 \\
\hline
\end{tabular}

\section{Conclusion}

In this research, UAV technology produced two types of data, namely DEM and land use, which functioned as the input in tsunami hazard modelling. These two data are accurate and, thereby, can help predict the extent of inundation and tsunami-affected areas. Based on the modelling, the areas affected by tsunami disasters in the 4-m scenario were doubled when the inundation was 6 $\mathrm{m}$. Meanwhile, the extent of the affected areas increased by less than $40 \%$ from the $8-\mathrm{m}$ to $12-\mathrm{m}$ scenario. The potential loss in the 4-m scenario rose significantly (nearly 100\%) when the inundation reached $6 \mathrm{~m}$. The potential loss increased by less than $30 \%$ from the 8 -m to 12-m scenario. The most widely affected land use was agricultural land, while the land use with the most significant loss was the trading centre. Tsunami inundation modelling in Drini coastal area is particularly suitable for predicting the extent of tsunamis' impact and creating a database in risk assessment and loss estimation. The data can be further used as the basis for planning an evacuation route and disaster mitigation. However, the tsunami inundation model in this research requires further improvement because it has not considered the strength of tsunami waves, the time of occurrence, and wave refraction. Future research is recommended to take into account these factors in tsunami hazard analysis.

This research is part of the Excellence Research Grant for Higher Education (Penelitian Unggulan Perguruan TinggiPUPT), titled "Pemetaan Risiko Bencana Kepesisiran menggunakan Teknologi Unmanned Aerial Vehicle (UAV) dan
GIs pada Wilayah Kepesisiran Kabupaten Gunungkidul”. Authors gratefully acknowledge the research funding and support from the Indonesian Ministry of Research and Higher Education.

\section{References}

1. Alberico, I., Di Fiore, V., Wavarone, R., Petrosino, P., Piemontese, L., Tarallo, D., ... Marsella, E. The Tsunami Vulnerability Assessment of Urban Environments through Freely Available Datasets: The Case Study of Napoli City (Southern Italy). Journal of Marine Science and Engineering, 3, 9811005 (2015)

2. Engel, M. \& Brückner, H. The Identification of Paleo-tsunami Deposits: a Major Challenge in Coastal Sedimentary Research. Coastline Reports, 17, 65-80. (2011)

3. Papadopoulos, G, A., Gràcia, E., Urgeles, R., Sallares, V., De Martini, P,M., Pantosti, D., González, M., Yalciner, A, C., Mascle, J., Sakellariou, D., Salamon, A., Tinti, S., Karastathis, V., Fokaefs, A., Camerlenghi, A., Novikova, T., Papageorgiou, A.. Historical and pre-historical tsunamis in the Mediterranean and its connected seas: Geological signatures, generation mechanisms and coastal impacts. Marine Geology 354 (2014)

4. Attary, N., Unnikrishnan, V, U., van de Lindt, J, W., Cox, D, T., Barbosa, A, R. Performance-Based Tsunami Engineering methodology for risk assessment of structures. Engineering Structures 141, 676-686 (2017)

5. Cankaya, Z.C., Suzen, M.L., Yalcineer, A.C., Kolat, C., Zaytsev, A., Aytore, B. A new GIS-based tsunami risk evaluation: MeTHuVA (METU tsunami human vulnerability assessment) at Yenikap1, Istanbul. Springer Juornal. (2016)

6. Dias, F., Dutykhc, D., O’Brien, L., Renzia, E., Stefanakis, T. 2014. On the modelling of tsunami generation and tsunami inundation. Procedia IUTAM 10338 - 355 ( 2014 )

7. Subandono, D. \& Budiman. Hidup Akrab dengan Gempa dan Tsunami. Bogor: Penerbit Buku Ilmiah Populer. (2008)

8. Dewi RS \& Dulbahri. Bencana Tsunami Parangtritis. In M.A. Marfai and D. Mardiatno (Eds), Penaksiran Multirisiko Bencana di Wilayah Kepesisiran Parangtritis (pp). Yogyakarta: Pusat Studi Bencana (PSBA) Universitas Gadjah Mada (2009)

9. Hartoko, A., Helmi, M., Sukarno, M., \& Hariyadi. Spatial Tsunami Wave Modelling for the South Java Coastal Area, Indonesia. International Journal of Geomate, 11(25), 2455-2460, (2016)

10. Marfai MA, King L Potential vulnerability implications of coastal inundation due to sea level rise for the coastal zone of Semarang City, Indonesia. Environmental Geology 54:1235-1245 (2008) 
11. Sutikno. Indonesia Negeri 1001 Bencana. Makalah dalam Seminar Sistem Informasi Kebencanaan Sebagai Sebuah Kearifan di Negeri 1001 Bencana. Environmental Geography Srudent Association (unpublished) Fakultas Geografi UGM Yogyakarta, 3-5 Desember (2009)

12. Verstappen, H.Th.. Outline of The Geomorphology of Indonesia. Enschede: ITC. (2000)

13. Adyan, Ö. . Seismic and Tsunami Hazard Potentials in Indonesia with a special emphasis on Sumatra Island. Journal of the School of Marine Science and Technology, Tokai University, 6(3), 19-38. (2008)

14. Lavigne, F., Gomez, C., Gifo, M., Wassmer, P., Hoebreck, C., Mardiatno, D. Paris, R. Field observations of the 17 July 2006 Tsunami in Java. Natural Hazards and Earth System Sciences, 7 (1):177-183. (2007)

15. Okamoto, T. \& Takenaka, H. Waveform inversion for slip distribution of the 2006 Java tsunami earthquake by using 2.5D finite-difference Green's function. Earth Planets Space, 61, 17-20 (2009)

16. Dao, H., Peduzzi, P, Global Evaluation of Human Risk and Vulnerability to Natural Hazards, Enviroinfo vol. I: 435-446. (2004)

17. Dewan, A, M., Floods in a Megacity: Geospatial Techniques in Assessing Hazards, Risk and Vulnerability, New York: Springer (2013)

18. Jaimes, M, A., Reinoso, E., Ordaz, M., Huerta, B., Silva, R., Mendoza, E., Rodríguez, J, C. 2016. A new approach to probabilistic earthquake-induced tsunami risk assessment. Ocean \& Coastal Management 119: 68-75 (2016)

19. Browning, J., Thomas, N. An assessment of the tsunami risk in Muscat and Salalah, Oman, based on estimations of probable maximum loss. International Journal of Disaster Risk Reduction 16, 75-87 (2016)

20. Ward, P, J., Marfai, M, A., Yulianto, F., Hizbaron, D, R., Aerts, J, C, J, H.. Coastal inundation and damage exposure estimation: a case study for Jakarta. Nat Hazards , 56,899-916 (2011)

21. Watanabe, Y, Kawahara,Y.. UAV photogrammetry for monitoring changes in river topography and vegetation. Procedia Engineering 154, 317 - 325 (2016)

22. Yan, L., Gou, Z., Duan, Y. A UAV Remote Sensing System: Design and Test. Geospatial Technology for Earth Observation, DOI 1 (2009)

23. Suparwati, T.; dkk. Geoekologi Kepesisiran dan Kemaritiman Daerah Istimewa Yogyakarta, Yogyakarta : Parangtritis Geomaritime Science Park (PGSP) (2016)

24. Schneider, B., Hoffmann, G., Reicherter. Scenariobased tsunami risk assessment using a static flooding approach and high-resolution digital elevation data: 139, 183-194 (2016) 